\title{
Knowledge level of the Farmers on SRI Method of Paddy Cultivation
}

\author{
Channamallikarjuna D., Syed Sadaqath
}

\author{
Department of Agricultural Extension, University of Agricultural Sciences, Dharwad, Karnataka, India
}

\begin{abstract}
The present study was conducted in Dharwad district of Karnataka, where in some parts are coming under paddy growing area and also as it comprises more rainfall with a maximum area under paddy cultivation. Fifteen SRI method paddy crop growers from each village were randomly selected to constitute the total sample size of 150. Structured interview schedule was used to collect the information through personal interview. Data was analyzed by using suitable statistical tools. The major findings of the study revealed that Paddy growers had medium (41.33\%) knowledge level where as minimum of 30.67 and the least of 28.00 per cent of respondents had high and low knowledge level, respectively.
\end{abstract}

Keywords-knowledge, SRI method paddy.

\section{INTRODUCTION}

Rice is life for millions of people in the world where more than 90 per cent of rice is grown and consumed. In India, rice is grown in about 44 million hectares (Mha) with a production of 90 million tons (Mt) annually. Annual rice production needs to be enhanced from the present $90 \mathrm{Mt}$ to about $100 \mathrm{Mt}$ by the end of eleventh plan period to meet the growing demand due to rapidly increasing population. This increase in production has to come despite the declining resources like land and water, which is a daunting task. Karnataka is one of the major rice growing states in India. It is grown in an area of (1.39 million ha) with an annual production of (4.04 million tonnes) in 2011-12. The area under rice production is increasing over the years.

System of Rice Intensification (SRI) is popular system of production of rice. SRI method cultivation of rice is considered to be a disembodied technological breakthrough in paddy cultivation. SRI method involves the application of certain management practices, which together provide better growing conditions for rice plants, particularly in the root zone, than those for plants grown under traditional practices. This system seems to be promising to overcome the shortage of water in irrigated rice. SRI methodology involves a set of practices for nursery, plant, soil, water and nutrient management. The convergence of changes in the way that plants, soil and water are best managed and expected production is known as the System of Rice Intensification. This technology tries to change traditional practices especially with respect to water management that existed for thousands of years. The full potential of SRI method of cultivation is realised with the following six important practices are adopted together due to their synergistic interactions.

\section{METHODOLOGY}

The present study was conducted in Dharwad district of Karnataka. The Research design adopted for the study was Expost-facto-research design was used for the study. 15 SRI method paddy crop growers from each village were randomly selected to constitute the total sample size of 150. The "teacher made test" as suggested by Anastasi (1961) was employed to measure the knowledge level of the respondents about the SRI method of cultivation practices. The answers to the question were quantified by giving one score to correct answer and zero score to incorrect answer. The test constituted 26 knowledge questions. The questions covered full range of cultivation practices beginning from land preparation till the crop yield. Depending upon the total scores obtained by each one of the respondents, they were grouped into three categories with mean and standard deviation as a measure of check. The data was analyzed by using appropriate statistical tools. The statistical tools such as mean, standard deviation, frequency and percentage were employed wherever found appropriate and data were analyzed to draw valid inferences.

\section{RESULTS AND DISCUSSIONS}

\section{Overall knowledge level of respondents}

It is evident from the data in Table 1 that a maximum of 41.33 per cent of the respondents had medium level of knowledge, where as minimum of 30.67 and the least of 28.00 per cent of respondents had high and low knowledge level, respectively. The overall knowledge gained by farmers on their exposure about SRI method cultivation of paddy crop.

The profile analysis of respondents revealed that, majority of them were middle aged grouped. With respect to education, farmers studied up to primary school. It is a fact that, as the age and education level increases, the 
level of knowledge also increases in addition the standard of living will also be better. Major proportion of the respondents were having marginal land holding. In the study area fifty per cent of the respondents were practicing SRI method cultivation of paddy in an area of up to 0.5 acre. This might be due to the fact that the farmers have cultivated paddy crop under SRI method as trial and hence only a small portion of land was committed to this intervention.

This find is in conformity with the findings of Khule et al. (2008), Mahatab Ali (2010), Gungadi (2011).

Knowledge level of respondent's individual SRI method of paddy cultivation practices by farmers

Table 2 reveals that the knowledge of SRI method paddy crop growers about individual cultivation practices of SRI paddy crop. It is interesting to note that a maximum of 85.33 per cent of the respondents had gained knowledge about both preparation of raised seed bed as well as seed treatment, followed by 84.00 per cent, of the respondents knew about soaking seed, a maximum of 83.33 per cent of the respondents had knowledge about seed rate @ 2 $\mathrm{kg} / \mathrm{acre}$ and seed treatment 77.33 per cent of the respondents had knowledge about application of fine powdered FYM is recommended before sowing seeds in nursery bed. While a maximum of, 75.33 per cent of the respondents had knowledge about "area required raising seedlings", these practices are important aspects of cultivation of SRI method paddy crop and do not vary much with other crops' cultivation practices because in SR method paddy nursery field there is chance of loss of young seedlings due to adverse climate conditions like heavy rains, occurrence of pest and disease. Therefore more than half of the respondents found to have knowledge about these basic cultivation practices.

Similarly, majority of 90.66 per cent of the farmers were having knowledge about recommended age of seedlings transplanting helps in inducing more number of tillers in main field, and 88.00 per cent of farmers have knowledge to utilising single seedlings per hill, transplanting single plant given more space and for better aeration and vigor plant growth, there by helps in getting more number of tillering and to increase in yield level and followed by the exact knowledge of recommended space adopted $25 \mathrm{~cm} \times$ $25 \mathrm{~cm}$ by 83.33 per cent of respondents. Further it is to be note that little more than seventy nine per cent of them had knowledge about recommended depth of transplanting of seedlings $(2-3 \mathrm{~cm})$ per hill. Where in Water consumption will be very less, soil become more fertile than in conventional method, and also helps in inducing more tillers in main field, with health and faster growth of seedlings are obtained, and also good quality of grain will obtained.
The correct knowledge of quantity FYM of application to SRI method paddy cultivation was known by a majority 86.66 per cent of the farmers. With regard to time of application and zinc application, 84.66 per cent of farmers expressed their views that better time for application of FYM within 2-3 weeks before transplanting. The paddy cultivating farmers understand that the application of FYM will gradually incorporate with the soil for providing congenial condition to soil texture which results better growth and development of paddy crop. And almost 58.00 per cent of the farmers had knowledge about chemical fertilizers. Regarding zinc application to crop growth a maximum of 58.00 per cent of farmers cultivating SRI method paddy cultivation have better knowledge level towards a zinc application because of the exposure to various method of cultivation crop and followed this application for better crop growth and increase in grain yield. Similarly, as high as 28.66 per cent of respondents are aware of green manureing crop will mix with soil and there by decomposes well in the puddling condition and improve the soil texture and supplement the nitrogen to the crop growth which results better yield level in SRI method cultivation.

In case of knowledge about stagnation of water level in the cultivated plots for about ten days after transplanting was known by maximum 90.66 per cent of respondents and a maximum of 92.00 per cent of respondents had correct knowledge about stagnation of water level at the time of flowering stage. Which facilitates better crop growth, better tillering leads to higher grain yield. With respect to weed management, majority of 78.67 per cent of farmers had knowledge about manual /hand weeding and as high 73.33 per cent of farmers are aware of mechanical method of weeding practices. To eradicate weeds in the cultivable crop since weeding is an important practice in SRI method of paddy crop and also weeds can be incorporated into soil by means of mechanical weeder which supplements nutrients to the soil. More over timely weeding operation helps to facilitate better crop growth and to get more yields.

The SRI method paddy crop growers knew some of the major crop incidence on paddy crop with their acquired knowledge. The study revealed insect that a considerable majority of 88.00 per cent of the respondents were generally aware of paddy hispa a major pest and its control measures, similarly little more than eighty two per cent of respondents had knowledge about incidence of stem borer and its control measures, and some what more than seventy eight per cent 78.66 per cent of them had knowledge about attack of brown plant hopper incidence on crop (BPH) and its control measures. The farmers observed that low incidence of pests in SRI method paddy cultivation was less when compared to conventional 
method paddy cultivation because of their earlier experience of conventional method of paddy cultivation there by the farmers gained more experience in cultivating SRI method and gained much knowledge about pest incidence.

Further, majority of the respondents had gained correct knowledge about disease incidence by diagnosing blast disease and its control measure of 90.66 per cent, followed by brown spot disease, and its control measure of 86.66 per cent and also incidence of bacterial leaf blight along and its control measure of 76.66 per cent. The reason of immediate attending regarding controlling the more pest and disease control by farmers may be due to knowledge on pesticides and fungicides with acquired knowledge by more exposure towards SRI method of paddy cultivation

With respect to yield, majority of 87.33 per cent of respondents' had correct knowledge about the higher potential yield that they may be obtained from one acre of land in SRI method, may be by-means of participating in some of the training programmes conducted by NGO'S extension worker, field days, exposure visit to SRI paddy method cultivation fields.

This trend of findings might be due to the fact that, farmers might have acquired knowledge about recommended SRI method of paddy cultivation practices by means of exposure visit, trainings, seminars, field days, by the SRI method paddy crop growing farmers.

Since the respondents had better exposure, higher income level with middle age group having, better education, and much experience in SRI method cultivation, with creativity of new ideas, more exposure to mass medias, better advisory services and quite good number of farmers participated in Farmers Field School field days etc. All these factors might have influenced the respondent's farmers to acquire more knowledge about SRI method paddy cultivation. It is quite natural that if the individual is having higher education, more land holding, and more mass media exposures with higher income have ambition to acquire more knowledge about new technologies and would like to earn more profit and improve the standard of living. The present findings were in accordance with the results reported by Manjunath (2010) and Gungadi (2011).

\section{CONCLUSION}

There is a need to encourage the farmers to cultivate more area under SRI paddy and promote SRI method of paddy cultivation among farmers in view of this Extension workers and concerned developmental departments personal to create awareness among farmers. The performance of SRI paddy was found to be good compare to traditional method of paddy cultivation. Hence, there is a need to extension organizations, developmental departments and NGO's should take necessary steps to promote SRI methodology in other paddy growing regions of the state and country. A research study covering all paddy growing districts in different agroecological zones of the state may be planned. This may help to find out zone specific problems and to fill up the scientific gaps in cultivation. Based on this, proper extension strategies could be developed by the planners and policy makers. The same may be proposed for implementation to ensure better adoption in cultivation practices.

\section{REFERENCES}

[1] Anastasi, A., 1961, Psychological Testing. The McMillan Company, New York.

[2] Gungadi, Sharanappa., 2011, A study on knowledge and adoption of recommended production practices of paddy by the farmers of Tungabhadra project area, Karnataka M. Sc. (Agri.) Thesis, Univ. Agric. Sci., Raichur, Karnataka (India).

[3] Khule, R. P., Lanjewar, D. M. and Jagdale, U. D., 2008, Knowledge level of paddy growers about low cost crop cultivation. Asian J. Extn. Edu., 17 : 25-28.

[4] Mahatab ali, K. M., 2010, A study on knowledge and adoption of aerobic rice growers in eastern dry zone of karnataka state M. Sc. (Agri.) Thesis, Univ. Agric. Sci., Bangalore, Karnataka (India).

[5] Manjunath, T., 2010, knowledge and adoption of plant protection measures by paddy growers of Raichur district, Karnataka. M. Sc. (Agri.) Thesis, Univ. Agric. Sci., Dharwad, Karnataka (India).

Table.1: Overall knowledge level of SRI method paddy farmers of recommended Cultivation practices

\begin{tabular}{|c|c|c|}
\hline Category & Frequency & Percentage \\
\hline Low $($ Mean $-0.425 *$ SD) & 42 & 28.00 \\
\hline Medium $\left(\right.$ Mean $\left.\pm 0.425^{*} \mathrm{SD}\right)$ & 62 & 41.33 \\
\hline High $($ Mean + 0.425*SD) & 46 & 30.67 \\
\hline
\end{tabular}


Table. 2: Knowledge of SRI method paddy farmers on individual recommended cultivation practices

$(\mathrm{n}=150)$

\begin{tabular}{|c|c|c|c|}
\hline \multirow{2}{*}{$\begin{array}{l}\text { Sl. } \\
\text { No }\end{array}$} & \multirow{2}{*}{ Practice } & \multicolumn{2}{|c|}{ Knowledge } \\
\hline & & $\mathbf{F}$ & $\%$ \\
\hline \multirow[t]{7}{*}{1.} & Nursery & & \\
\hline & Preparation of raised seed bed & 128 & 85.33 \\
\hline & Soaking seed for $24 \mathrm{hrs}$ & 126 & 84.00 \\
\hline & Seed treatment & 128 & 85.33 \\
\hline & Seed rate@2 Kg/ac & 125 & 83.33 \\
\hline & $\begin{array}{l}\text { Application of finely powdered organic manure before } \& \text { after } \\
\text { spreading of seed in nursery }\end{array}$ & 116 & 77.33 \\
\hline & Area $40 \mathrm{sq} \mathrm{m} / \mathrm{ac}$ & 113 & 75.33 \\
\hline \multirow[t]{4}{*}{2.} & Main field & & \\
\hline & Seedlings (1 per hill) & 132 & 88.00 \\
\hline & Age of seedlings (8-12 Days old) & 136 & 90.66 \\
\hline & Depth of transplanting $(2-3 \mathrm{~cm})$ & 119 & 79.33 \\
\hline 3. & Spacing $25 \times 25 \mathrm{~cm}$ & 125 & 83.33 \\
\hline \multirow[t]{3}{*}{4.} & FYM application & & \\
\hline & Quantity 4-5 tonnes /ac & 130 & 86.66 \\
\hline & Time of application (2-3 weeks before sowing) & 127 & 84.66 \\
\hline 5. & Green manure (Sesbania rostrata,sunhemp) & 43 & 28.66 \\
\hline \multirow[t]{3}{*}{6.} & Chemical fertilizer application & & \\
\hline & Chemical fertilizer application NPK $(50: 30: 20) \mathrm{Kg} / \mathrm{Ac}$ & 87 & 58.00 \\
\hline & Zinc application 2-3 Kg/ac & 127 & 84.67 \\
\hline \multirow[t]{3}{*}{7.} & Water management & & \\
\hline & Water level till 10 DAT $(2.5 \mathrm{~cm})$ & 136 & 90.66 \\
\hline & Water level at flowering stage $(2-3 \mathrm{~cm})$ & 138 & 92.00 \\
\hline \multirow[t]{3}{*}{8.} & Weed management & & \\
\hline & Mechanical weeding ( 10 DAT 3-4 weeding at 10 days interval) & 110 & 73.33 \\
\hline & Manual weeding (1-2 times) 45-75 DAT & 118 & 78.66 \\
\hline \multirow[t]{4}{*}{9.} & Major pests control & & \\
\hline & Brown plant hopper (Imidachloprid) & 118 & 78.66 \\
\hline & Stem borer (Carbofuron) & 124 & 82.66 \\
\hline & Paddy hisspa ( Quinolphos) & 132 & 88.00 \\
\hline \multirow[t]{4}{*}{10.} & Major Diseases control & & \\
\hline & Blast (Carbendazim) & 136 & 90.66 \\
\hline & Bacterial leaf blight (Blitex) & 115 & 76.66 \\
\hline & Brown Spot (Mancozeb) & 130 & 86.66 \\
\hline 11. & Yield $21-23$ quintals/ac & 131 & 87.33 \\
\hline
\end{tabular}

